\title{
Fen Öğretiminde REACT'ın Etkileri: 21. Yüzyıl Becerileri ve Fene Yönelik Öz Yeterlilik İnançları
}

\author{
DOI: 10.26466/opus.701189
}

\author{
* \\ Huriye Deniş Celiker* - Muhammed Kara** \\ * Doç. Dr., Burdur Mehmet Akif Ersoy Üniversitesi, Eğitim Fakültesi \\ E-Posta: huriyedenis@mehmetakif.edu.tr \\ ORCID: 0000-0001-8059-6067 \\ ** Fen Bilimleri Öğretmeni, Antalya-Elmalı Ömerpaşa Ortaokulu \\ E-Posta: drmuhammedkara@gmail.com \\ ORCID: 0000-0002-6634-563X
}

\begin{abstract}
Öz
Bilim ve teknolojide yeni gelişmeleri sağlamak ve var olan problemlere çözüm üretebilmek eğitimle mümkündür. Ĕ̆itim bu anlamda yeni bir gösterimi ortaya koymalıdır. Bu gösterimde öğrencilerin gerçek yaşamla kuracakları bağlam oldukça önemlidir. Bu çalışmada 8. sınıf elektrik yükleri ve elektrik enerjisi ünitesinde bağlam temelli öğrenme stratejilerinden REACT'ın öğrencilerin 21. yüzyıl becerilerine ve fen öğrenmeye yönelik öz yeterlik inançlarına etkisinin belirlenmesi amaçlanmaktadır. Öğrencilerde fen öğrenmeye yönelik öz yeterlik inancmn ve 21. yüzyıl becerilerini geliştirmede bağlam temelli öğrenmenin bir uygulama alan olan REACT stratejisinin etkilerinin belirlendiğ i bu çalışmada yarı deneysel desenlerden eşitlenmemiş gruplarla ön test-son test modeli kullanılmıştır. Uygulamanın çalışma grubunu 37 8. sını öğrencisi oluşturmaktadır. Veri toplama aracı olarak 21. yüzyıl becerileri ölçeği ile fen öğrenmeye yönelik öz-yeterlik inanç ölçeği kullanılmıştır. Deney grubunda REACT stratejisine uygun etkinlikler uygulanmıştır. Kontrol grubu öğrencileri ile 2018 fen bilimleri dersi öğretim programı çerçevesinde dersler yürütülmüştür. Verilerin analizinde SPSS paket programından faydalanılmıştır. Araştırma sonucunda deney ve kontrol grubunun ön testlerinde anlamlı bir fark olmadığını, son testlerde ise 21. yüzyıl becerileri ve fene yönelik öz yeterlilik inançlarında deney grubu lehine anlaml bir fark bulunmuştur.
\end{abstract}

Anahtar Kelimeler: 21. yüzyıl becerileri, Fen öğrenmeye yönelik öz-yeterlik inançları, Fen eğitimi, REACT stratejisi. 


\title{
React's Effects In Science Teaching: 21st Century Skills And Science Self-Efficiency Beliefs
}

\begin{abstract}
It is possible to provide new developments in science and technology and to produce solutions to existing problems through education. In this sense, education should reveal a new representation. In this demonstration, the context that students will establish with real life is very important. In this study, it is aimed to determine the effect of REACT, one of the context-based learning strategies in 8th grade electrical loads and electrical energy unit, on students' 21st century skills and self-efficacy beliefs towards learning science. In this study, the effects of REACT strategy, which is an application area of context-based learning, in the development of self-efficacy beliefs and 21st century skills in science learning were determined in this study. The study group consists of 37 th grade students. The 21st century skills scale and the self-efficacy belief scale for learning science were used as data collection tools. In the experimental group, activities in accordance with REACT strategy were applied. Courses were conducted with the control group students within the framework of the 2018 science curriculum. SPSS package program was used for data analysis. As a result of the research, it was found that there was no significant difference in pre-tests of experimental and control groups and in post-tests a significant difference was found in favor of experimental group in 21st century skills and self-efficacy beliefs towards science.
\end{abstract}

Keywords: 21st century skills, Self-efficacy beliefs towards learning science, Science education, REACT strategy. 


\section{Giriş}

Teknoloji ve bilimde yaşanan gelişmelere rağmen, iklim değişikliği, biyolojik çeşitlilik kaybı, enerji kaynakları için rekabet, temiz suya erişim, hava kirliliği ve arazi bozulması gibi sorunlar, ülkeler için temel zorluklar ve sorunlar olmaya devam etmektedir (Hokayem ve Jin, 2019). Eğitim, ise bu sorunları çözebilecek bağlamları kurabilen, çoklu bakış açıları oluşturan bir sistemdir (Castro, 2019). 21. yüzyılda öğrencilere sunulan eğitim, ihtiyaçlarımıza cevap verebilmek ve hedefimiz doğrultusunda anlamlı bir rol oynayabilmek adına yeni bir gösterim ortaya koymalıdır (Holbrok, 2010). Her alanda yaşanan değişimleri öngörüp, talepleri karşılayabilmek için eğitimde faydalı çıktılar elde edilmelidir (Rojewski ve Hill, 2017). Bilgi toplumlarında yeni bilgilere nasıl ulaşacağını, nasıl yorumlanacağını, ileteceğini ve aranacağını bilmek başarılı bir vatandaş olabilmek için anahtar becerilerdir (Mioto, Petri, Wangenheim, Borgatto ve Pacheco, 2019). Öğrenme teknolojilerindeki ve öğrenme ortamlarındaki sık değişiklikler nedeniyle, 21.yüzyıl becerileri sürekli değişmekle birlikte işbirliği, iletişim, yaratıcılık, eleştirel düşünme, bilgi okuryazarlığı, sorun çözme ve sosyo-duygusal becerilerinden oluşmaktadır (Silber-Varod, Eshet-Alkalai ve Geri, 2019). Öğrencilerin ise geleceğin vatandaşı olarak 21. yüzyılda her zaman değişebilecek koşullara yaşamaya hazırlanmaları gerekir (Dewi, Nurfajar ve Dardiri, 2019). Gerçek eğitimde, bir çocuk okulda bu bilgileri yaşamlarında uygulayabilmesi ve farklı açılardan karşılaştı̆̆ı sorunları çözebilmesi için edinir (Suryaningtyas ve Halimah 2017). Öğretmenler ise bu konuda yeni gelişmeler ile günlük yaşam arasında bağlantılar kurup öğrencilerin bilime ulaşma olanaklarını arttırmalıdır (Royce, 2019). Öğretim programlarında öğrencilerin uygulamalara katılabilecekleri konulara ağırlık verilmelidir (Brown, 2019). Türkiye'de Fen Bilimleri dersi öğretim programında bilimin daha çok uygulamalı olarak ekonomiye katkı sağlaması niteliği önemsenmiştir. Bu bağlamda her bir ünite, konu ve kazanım günlük hayat ihtiyaçlarını gidermeye yönelik teknolojiler üretilmesini gözeten bir yaklaşımı benimsemiştir. Bilimsel süreç becerisi olarak araştırma ve sorgulama becerileri, yaşam becerileri olarak analitik düşünme, karar verme, yaratıcılık, girişimcilik, iletişim ve takım çalışması gibi beceriler ve mühendislik ve tasarım becerileri programda yer almaktadır. Hedeflenen kazanımlar uygulamalarla öğrencilerin günlük yaşam bağlantısını kurmalarına ve öğrendiklerini yaşantısal hâle getirerek kendilerini 
geliştirmelerine yardımcı olmaktır (Milli Eğitim Bakanlı̆̆ı, 2018). Eğitim reformları için öğretim programları düzenlenirken ulusal ve uluslararası araştırmalar/sınavlardan elde edilen sonuçlar önemli bir kaynak oluşturmaktadır. Ekonomik İşbirliği ve Kalkınma Teşkilatı tarafından yapılan Uluslararası Öğrenci Değerlendirme Programı (PISA) bu kapsamda uluslararası düzeyde yapılan en kapsamlı eğitim araştırmalarından biridir. PISA sınavı öğrencilerin, olguları bilimsel olarak açıklayabilme, bilimsel sorgulama yöntemi tasarlayabilme ve değerlendirme ile verileri ve bulguları bilimsel olarak yorumlayabilme yeterliliklerini ölçmektedir. PISA araştırmalarının her bir döngüsünde temel alanlardan biri ağırlıklı alan olarak belirlenmektedir. Bu alanlardan biri de fen okuryazarlığıdır. Fen okuryazarlığı değerlendirme çerçevesinin genel özelliklerine bakıldığında öğrencilerden biraz fen ve teknoloji bilgisi gerektiren kişisel, yerel/ulusal ve küresel sorunlar ile bağlam kurabilmeleri istenmektedir (Taş, Arıcı, Özarkan ve Öztürk, 2016). Bağlam temelli öğrenmenin özelliklerinin PISA sorularının karakteristikleri ile oldukça örtüşmekte, TIMSS sorularının bir kısmı da bağlamsal problemlerden oluşmakta, ama ülkemiz sınav sorularında bu tür problemlerle çok nadir karşılaşılmaktadır (Değirmenci ve Karamustafaoğlu, 2019). PISA fen bilimleri test soruları günlük hayatla karşılaşılacak konulardan değerlendirme üniteleri şeklindedir (Acar ve Öğretmen, 2012). Ülkemizdeki eğitim sistemi ile günlük yaşam bağlamı kurulamadığı için ülkemizin fen bilimleri okuryazarlığı açısından PISA sınavlarındaki sıralaması Ekonomik İşbirliği ve Kalkınma Örgütü'nün (OECD) verilerine göre ülke ortalamalarının altında kalmaktadır. Verilen bilgilerin günlük hayatla bağlantısını kurmamak her öğrenim kademesinde karşılaşılan bir durumdur. Öğrencilerin “Bu bilgiler bizim ne işimize yarayacak?" sorusuna yıllar yılı öğretmenlerin verdiği cevap sadece sınavda çıkabilir gerekçesi olmuştur. Öğretmenlerimiz kavram ve konuların öğretiminde o konu ya da kavram kendilerine nasıl öğretilmişse aynı şekilde öğretim yapmışlardır. Merkezi sınavlarda alınan sonuçlara bu durumun yansımaları yıllarca görülmüştür (Çepni, 2016).Bu nedenle öğrencilerin okuldaki fen kazanımları ile günlük hayatta karşılaştıkları problemlerini çözebilmeleri, toplumsal ve bilimsel sorunların farkında olmaları, güncel ihtiyaçlarını karşılayabilmeleri sağlanmalıdır. Bu anlamda öğrencilerin kavramlar ve bağlam arasındaki bağlantılarını geliştirmelerinde bağlam temelli yaklaşım umut veren bir yaklaşımdır (King ve Henderson, 2018). Bağlam temelli öğrenme aynı zamanda öğrencilerin bilimsel 
metin kavramalarını teşvik eden ve üst bilişsel becerileri geliştiren bir yaklaşımdır (Dori, Avargil, Kohen ve Saar, 2018). Sonuç olarak öğrencilerin bir konuyu niçin öğrenmeleri gerektiğinin farkına varabilmeleri günlük yaşamla kurulan bağlamla mümkündür. Karşılaşılan durumlar bilimsel kavramlarla açıklanabildiği takdirde öğrenci başarılı olacaktır. Uluslararası Öğrenci Değerlendirme sınavları da öğrencilerin bağlam kurabilme durumlarını ölçmektedir. Bağlam temelli öğrenmenin uygulama yollarından biri de REACT stratejisidir (Demircioğlu, Vural ve Demircioğlu, 2012). Bu strateji fen bilimlerinde de kullanılmaktadır (Coştu, 2009). REACT stratejisine göre planlanmış bir eğitim sürecinin hem öğrencilerin bağlamı kurabilmelerine hem de fen öğrenmeye yönelik öz yeterlilik becerilerinin gelişmesine yardımcı olacağı düşünülmektedir. Bandura'ya (1977) göre insanların bir işi olumlu bir şekilde sonuçlandırabileceklerine emin olmaları yani özyeterlilik inançlarının güçlü olması o işi yapma konusunda daha istekli olmalarını sağlar. Öğretmenlerin öğrencilerin özyeterlilik becerilerini geliştirmeleri öğrencilerde akademik başarıyı arttımakta, özellikle de başarısız öğrenciler üzerinde olumlu bir etki oluşturmaktadır (Jinks ve Lorsbach, 2003). Günlük yaşamda bir başkasının yaşadığı, öğrenci için dolaylı yaşantı olabilecek durumlar öğrencide var olan özyeterlilik inançlarının önemli bir kaynağıdır (Arslan, 2012). Bağlam temelli öğrenmenin öğrenciye, dolaylı yada doğrudan gerçekleşecek yaşantıları sunabilmesinin öğrencide özyeterlilik inancının gelişmesinde katkısı olacağı düşünülmektedir.

Fen eğitimi oldukça geniş bir alandır. İnsanlığın bilim, teknoloji ve mühendislik alanlarındaki gelecekteki gelişimi için bilim eğitimi kalkınma çabalarının sınırlarını ilerletmede önemli bir rol oynamaktadır (Taber ve Akpan, 2016). Çağdaş fen uygulamaları yapılandırmacı düşünce üzerine kurulmuştur. Yapılandırmacılık eğitimde araştırma, öğretim programı geliştirme için bir referans olarak geniş çapta kabul edilmiştir (Taber, 2016). Bağlam temelli öğrenme de yapılandırıcı yaklaşımı temel alır. Günlük yaşam örneklerine dayalı ilişki kurması yönüyle de diğer teorilerden farklılaşmaktadır (Bennett, Hogarth ve Lubben, 2003). Bağlam temelli öğrenme Amerika'da eğitimde değişim hareketi olan Center for Occupational Research and Development (CORD) grubu tarafından çeşitli projeler üzerinden anlatılmış ve alanında başarılı olmuş ve fark yaratan öğretmenlerin sınıflarında nasıl bir yöntem kullandıkları araştırılmıştır. Sonuç olarak beş adımda Relating, Experiencing, Applying, Cooperating, and Transferring yani kısaca REACT 
stratejisi tanıtılmıştır (CORD, 1999). REACT stratejisi, öğrencilerin öğrenecekleri ile deneyimleri arasında bağlantı kuran ilişkilendirme (Relating), kurulan bağlamın sınıf içinde tecrübe etmelerini sağlayan (Experiencing), ilişkiyi tecrübe ettikten sonra bağlamın mesleki boyutuna vurgunun yapıldığı uygulama (Applying), arkadaşları ile iletişimin ve paylaşımın gerçekleştiği iş birliği (Cooperating) ve öğrenilenlerin yeni bir bağlamda kullanıldığ transfer etme (Transferring) basamaklarını içerir (Crawford, 2001). Yapılan çalışmalar öğrencilerin fen bilimlerine olan ilgilerini artırmanın en önemli yolunun bilimsel bilgileri günlük yaşamdaki olaylarla ilişkilendirmekten geçtiğini göstermektedir (Potter ve Overton, 2006). Bu yönüyle düşünüldüğünde bağlam temelli öğrenmenin bir uygulaması olan REACT stratejisi öğrencilere iyi bir fen eğitimi sunmada iyi bir araçtır. İlgili alanyazIn incelendiğinde, ortaöğretim düzeyinde kimya ve fizik derslerinde REACT stratejisi uygulamalarının öğrencilerin başarılarına (Karslı ve Yiğit, 2015; Demircioğlu, Kurnaz ve Erol, 2017; Gül, Gürbüzoğlu Yalmancı ve Yalmancı, 2017; Demircioğlu, Bektaş ve Demircioğlu, 2018; Ayvacı ve Bilge, 2018; Ültay, 2014; Yiğit, 2015) etkisinin belirlenmesine yönelik çalışmalara rastlanmaktadır. Mevcut çalışmalar genellikle ortaöğretim seviyesinde kimya ve fizik konuları üzerine yapılmıştır. Fen konularında farklı öğrenim seviyelerinde REACT stratejisiyle ilgili akademik başarıya, fen okuryazarlık düzeyine, kavramsal anlamaya, bağlamları günlük yaşamla ilişkilendirmeye, tutum ve deneyimler üzerindeki etkisine dönük çalışmalar bulunmaktadır (Kirman Bilgin, 2015; Sevinç, 2015; Ültay, 2012; Kirman Bilgin ve Yiğit, 2017a; Kirman Bilgin ve Yiğit, 2017b; Keskin ve Çam, 2019; Ayvacı, Er Nas ve Dilber, 2016). Bu açıdan yapılan çalışmaların az olduğu görülmektedir. Bu çalışmayla elde edilen sonuçlar, öğrenilen konuların günlük yaşam bağlamının kurulması, yaygınlaştırması, öğrenmenin kolaylaştırması açısından önemlidir. Eğitim sürecinin tüm paydaşlarının yararlanabileceği bir çalışmadır. Fen derslerinde elektrik konusunu içeren üniteler ile ilgili yapılan çalışmalar incelendiğinde farklı model, yöntem ve tekniklerin akademik başarı, kalıcılık, bilimsel süreç becerilerine, kavramsal anlamaya, kavramsal değişime, kavram yanılgılarının giderilmesine, kavramlarının gelişimine ve duyuşsal ve psikomotor becerilerine etkisini araştırdıkları (Ateş ve Polat, 2005; Aydoğdu ve Ergin, 2008; Demirci ve Yağc1, 2008; Karakuyu ve Tüysüz, 2011; Ayvacı ve İpek Akbulut, 2012; Daşdemir ve Doymuş, 2012; Gürbüz, Turgut ve Salar, 2013; Aymen Peker, Taş, Apaydın ve Akman, 2014; 
Bozat ve Yıldız, 2015; Küçük ve Çalık, 2015), öğretim programında öngörülen kazanımların kazanılma düzeyini inceledikleri (Keser ve Başak, 2013), başarıları üzerinde okulun yerleşim yeri değişkeninin etkisinin incelendiği (Eş ve Sarıkaya, 2010), görme engellilerde etkinlik kullanımının kavramsal öğrenmeye etkisinin araştırıldığı (Okcu ve Sözbilir, 2016), kavram yanılgılarının belirlendiği (Millar ve King, 1993; Küçüközer, 2003; Aykutlu ve Şen, 2012; Dilber ve Düzgün, 2003a, Dilber ve Düzgün, 2003b), üniteye yönelik bilimsel süreç becerileri ölçeğinin geliştirildiği (Aydoğdu ve Ergin, 2009) görülmektedir. Elektrik ünitesinde öğrenciler konu kavramlarını yorumlama ve sonuç çıkarma alanları ile ilgili sorunlar yaşanmaktadır (Keser ve Başak, 2013). Elektrik ünitesinde öğrenilenerin kalıcı olmadığı (Eş ve Sarıkaya, 2010), öğrencilerin elektrik konusu ile ilgili bilgi ve kavramları anlamakta zorlandıkları görülmektedir (Göçmençelebi, 2002). Elektrikle ilgili kavramlar, günlük dilde fende kullanıldığı bilimsel açıklamalardan farklı anlamlarda kullanılmaktadırlar (Karakuyu ve Tüysüz, 2011). Buda kavram yanılgılarına temel oluşturmaktadır (Duit ve Rhöneck, 1997). İlgili alanyazından yola çıkarak 8. Sınıfta yer alan elektrik ünitesinde kazanımlar ile günlük yaşam bağlamını kurmanın mümkün olması, ayrıca ünitenin süre açısından geliştirilen etkinliklerin uygulanmasına olanak tanıması araştırma kapsamında bu ünitenin seçilmesinde etkili olmuştur. Bu çalışmanın amacı REACT stratejisine göre planlanmış 8.sınıf elektrik yükleri ve elektrik enerjisi ünitesinin öğrencilerin 21.yüzyıl becerilerine ve fen öğrenmeye yönelik öz-yeterlik inançlarına etkisini araştırmaktır.

\section{Problem Cümlesi}

Araştırmanın problem cümlesi "REACT stratejisine göre planlanmış 8.sınıf elektrik yükleri ve elektrik enerjisi ünitesinin öğrencilerin 21.yüzyıl becerilerine ve fen öğrenmeye yönelik öz-yeterlik inançlarına etkisi var mıdır?" şeklindedir.

\section{Alt Problemler}

Araştırmanın alt problemleri aşağıdaki gibidir.

1. 2018 fen bilimleri dersi öğretim programı uygulanan öğrenci grubu ile üzerinde çalışma yapılan öğrenci grubu arasında uygulama öncesi ön 
test puanları arasında 21.yüzyıl becerilerinin gelişimi anlamında bir farklılık var midır?

2. 8.sınıf elektrik yükleri ve elektrik enerjisi ünitesinde REACT stratejisine göre planlanmış eğitim süreci ile 2018 fen bilimleri dersi öğretim programına göre planlanmış eğitim süreci arasında son test puanlarında 21.yüzyıl becerilerinin gelişimi anlamında fark var mıdır?"

3. 2018 fen bilimleri dersi öğretim programı uygulanan öğrenci grubu ile üzerinde çalışma yapılan öğrenci grubu arasında uygulama öncesi ön test puanları arasında fen öğrenmeye yönelik öz-yeterlik inançları anlamında bir farklılık var mıdır?

4. 8.sinıf elektrik yükleri ve elektrik enerjisi ünitesinde REACT stratejisine göre planlanmış eğitim süreci ile 2018 fen bilimleri dersi öğretim programına göre planlanmış eğitim süreci arasında son test puanlarında fen öğrenmeye yönelik öz-yeterlik inançları anlamında fark var mıdır?"

\section{Yöntem}

\section{Araştırmanın Modeli}

Araştırmada ön test-son test kontrol gruplu yarı deneysel desen kullanılmıştır (Karasar, 2009). Deneysel desenler değişkenler arasında neden-sonuç ilişkilerini keşfetmeyi amaçlayan araştırma desenleridir (Büyüköztürk, 2007). Yarı deneysel desen ile deneysel desen arasindaki temel fark kontrol ve deney gruplarını belirlerken seçkisiz atama yönteminin kullanılması ya da kullanılmamasıdır (Böke, 2009). Yarı deneysel desenler tüm değişkenlerin kontrol altına alınmasının mümkün olmadığı durumlarda en çok kullanilan deneysel desendir (Cohen, Manion ve Morrison, 2000). Creswel (2003), deneysel yöntemde deneklerin deney veya kontrol grubunda yer alacağının tamamen rastgele atama yöntemi ile belirlenmesi gerektiğini ifade etmektedir. Bu çalışmadaki toplam 2 şube 8. sınıf öğrencisi önceden oluşturulmuş sinıflardaki öğrencilerdir. Bu yüzden öğrencilerin deney ve kontrol gruplarına rastgele atanma imkânı olmamıştır. Sınıfların birisi rastgele deney, diğeri ise kontrol grubu olarak belirlenmiştir. 
Tablo 1. Araştırma Deseninin Gösterimi

\begin{tabular}{|c|c|c|c|}
\hline Gruplar & Ön test & Süreç & Son test \\
\hline Deney Grubu & $\begin{array}{l}\text { 21. Yüzyıl Becerileri ve Fen } \\
\text { Öğrenmeye yönelik Öz } \\
\text { Yeterlilik İnançÖlçeği }\end{array}$ & $\begin{array}{l}\text { REACT Stratejisine Göre Hazır- } \\
\text { lanmış Eğitim Materyalleri ̆le } \\
\text { Desteklenmiş Fen Bilimleri Dersi } \\
\text { Öğretim Programı }\end{array}$ & $\begin{array}{l}\text { 21. Yüzyıl Becerileri ve Fen } \\
\text { Öğrenmeye yönelik Öz } \\
\text { Yeterlilik İnanç Ölçeği }\end{array}$ \\
\hline Kontrol Grubu & $\begin{array}{l}\text { 21. Yüzyıl Becerileri ve Fen } \\
\text { Öğrenmeye yönelik Öz } \\
\text { Yeterlilik İnanç Ölçeği }\end{array}$ & $\begin{array}{l}2018 \text { Fen Bilimleri Dersi Öğretim } \\
\text { Programı }\end{array}$ & $\begin{array}{l}\text { 21. Yüzyıl Becerileri ve Fen } \\
\text { Öğrenmeye yönelik Öz } \\
\text { Yeterlilik İnanç Ölçeği }\end{array}$ \\
\hline
\end{tabular}

\section{Çalışma Grubu}

Araştırmanın örneklemi 2018 - 2019 eğitim öğretim yılında Antalya İli Elmalı ilçesinde bir ortaokulda öğrenim görmekte olan 37 ortaokul 8. sinıf öğrencisidir. Bu öğrenci grubu, çok çeşitli sosyo-kültürel seviyelerden oluşmaktadır, ilçe merkeziden gelen; maddi durumu iyi olan, ekonomik açıdan dezavantajlı olan; geniş aile içinde yetişen, çekirdek ailede yetişen öğrencilerin olması bu okulda bu çalışmayı yapmanın uygun olabileceğini düşündürmüştür. Zaman, para ve işgücü açısından var olan sınırlılıklar nedeniyle örneklemin kolay ulaşılabilir ve uygulama yapılabilir olması açısından araştırmada uygun örnekleme yöntemi kullanılmıştır. Araştırmada çalışılan grup istatistikleri aşağıdaki tabloda verilmiştir.

Tablo 2. Çalışma Grubunda Bulunan Katılımcı Sayısı ve Cinsiyete Göre Dağılımı

\begin{tabular}{llll}
\hline Grup & Kiz öğrenci & Erkek öğrenci & Toplam \\
\hline Deney grubu & 11 & 9 & 20 \\
\hline Kontrol grubu & 10 & 7 & 17 \\
\hline Toplam & 20 & 17 & 37 \\
\hline
\end{tabular}

\section{Veri Toplama Araçları}

21.yüzyıl becerileri ölçeği: Araştırmada Kang, Kim, Kim ve You (2012) tarafından geliştirilen, Karakaş (2015) tarafından Türkçeye uyarlanan 21. Yüzyıl Becerileri Ölçeği ölçme aracı olarak kullanılmıştır. Uyarlanan ölçekte özgün biçiminde 33 madde bulunmaktadır. Bu maddeler üç ana boyuttan (bilişsel, duyuşsal ve sosyokültürel) ve 21 alt boyuttan oluşmaktadır. Ölçeğin boyutlarına göre sınıflandırılması Tablo 3'da verilmiştir. Ölçek beşli likert tipi ölçek olup "1" Hiç Katılmıyorum, "2" Katılmıyorum, "3" Kararsızım, "4" Katılıyorum ve " 5 " Tamamen Katılıyorum şeklinde değerlendirilmiştir. 
Tablo 3. Ölçek Sorularının Alt Alanlan ve Maddeleri (Karakaş, 2015)

\begin{tabular}{lll}
\hline Alan & Alt Alan & Alt alana ait ölçek maddeleri \\
\hline \multirow{3}{*}{ Bilişsel } & Bilgi Yönetim Becerisi & $1,2,3,4$ \\
& Bilgi Yapılandırma Yeteneği & $5,6,7,8$ \\
& Bilgi Kullanma Yeteneği & 9,10 \\
& Problem Çözme Yeteneği & $11,12,13$ \\
\hline \multirow{3}{*}{ Duyuşsal } & Öz Kimlik & 14,15 \\
& Öz Değer & $16,17,18$ \\
& Kendi Kendini Yönetme & 19,20 \\
& Öz Sorumluluk & $21,22,23$ \\
\hline \multirow{2}{*}{ Sosyokültürel } & Sosyal Üyelik & 24,25 \\
& Sosyal Hassasiyet & $26,27,28$ \\
& Sosyalleşme Yeteneği & 29,30 \\
& Sosyal İfa & $31,32,33$ \\
\hline
\end{tabular}

Karakaş (2015) 21. yüzyıl Becerileri Ölçeğinin Türk kültüründe de orijinalindeki faktör yapısını gösterip göstermediğini incelemek için Doğrulayıcı Faktör Analizi yapmıştır. Doğrulayıcı faktör analizi sonucunda uyum iyiliği değerleri $\chi 2(\mathrm{sd}=461, \mathrm{~N}=245)=817,23 \mathrm{p}<0,05$. RMSEA=0,058, AGFI=0,70, S$\mathrm{RMR}=0,070$ ve $C F I=0,090$ olarak tespit edilmiştir. Doğrulayıcı faktör analizi sonucunda 32 maddenin toplam üç alt boyutta toplandiğ1 görülmektedir. Aynı zamanda bu üç alt boyut da tek bir boyut altında toplanmaktadır. Ölçeğin alt boyutlarına ilişkin Cronbach alfa katsayıları sırasıyla, .77, .70 ve. $67^{\prime}$ dir.

Fen Öğrenmeye Yönelik Öz-Yeterlik Inanç Ölçeği: Araştırmada Yaman (2016) tarafından geliştirilen fen öğrenmeye yönelik öz-yeterlik inanç ölçeği kullanılmıştır. Likert türdeki ölçme aracındaki dereceler "Kesinlikle katılmiyorum" ile "Kesinlikle katılıyorum" formatındadır. Maddelerin derecelerinin puanlanmasında olumsuzdan olumluya doğru puanlama, 1'den 5 rakamına doğru yapılmıştır. Ölçekteki puan aralığı 1,00 ile 5,00 arasında olduğundan, puanlar 5,00'e yaklaştıkça öğrencilerin fen öğrenmeye yönelik öz-yeterlik inanç düzeylerinin yüksek, 1,00'e yaklaştıkça düşük olduğu kabul edilmiştir. Yaman (2016) tarafından elde edilen ölçeğin toplam puanının ve alt faktörlerinin ölçüm güvenirlik katsayısına ilişkin veriler Tablo 4 ' de sunulmuştur.

Tablo 4. Ölçme aracının toplam puanının ve alt faktörlerin güvenirlik katsayı sonuçları

\begin{tabular}{llll}
\hline \multirow{2}{*}{ Faktörler } & $\begin{array}{l}\text { Madde } \\
\text { Sayısı }\end{array}$ & $\begin{array}{l}\text { AFA Örneklemi İçin } \\
\text { Cronbach Alfa Katsayıları }\end{array}$ & $\begin{array}{l}\text { DFA Örneklemi İçin } \\
\text { Cronbach Alfa Katsayısı }\end{array}$ \\
\hline Bireysel Başarıya Yönelik Öz Yeterlilik & 10 & 0,83 & 0,82 \\
Performansa Yönelik Öz Yeterlilik & 4 & 0,74 & 0,73 \\
Sonuca Yönelik Öz Yeterlilik & 3 & 0,69 & 0,66 \\
\hline Toplam & 17 & 0,85 & 0,83 \\
\hline
\end{tabular}


$\mathrm{Bu}$ çalş̧mada geliştirilen öz-yeterlik inanç ölçeğinin ilk boyutu bireysel başarıya yönelik öz-yeterliktir. Bu boyuttaki maddeler, öğrencilerin fen derslerinde akademik başarılarını artırmaya yönelik kendilerini öz yeterlik düzeylerini ortaya koymaktadır.

\section{Deneysel İşlem Yolu}

Araştırma bir ortaokulda öğrenim görmekte olan 37 sekizinci sınıf öğrencisi ile yürütülmüsşür. Deney ve kontrol grubu öğrencilerine yarı deneysel işleme başlamadan önce 21. yüzyıl becerileri ölçeği ile fen öğrenmeye yönelik öz-yeterlik inanç ölçeği ön test olarak uygulanıştır. Uygulamalar öğrencilerin normal ders süreci içinde haftada 4 saat olarak yürütülmüştür. Yarı deneysel çalışma 5 hafta süresince devam etmiştir. Ön ve son test uygulamalariyla 6 hafta sürmüştür. Deney grubunda REACT stratejisine göre planlanmış etkinlikler kullanılmıştır. Fen bilimleri yıllık planında ünite kapsamında toplam 10 adet kazanım bulunmaktadır. Bu kazanımlar konu bütünlüğü ve uygulama şartları gereklilikleri dikkate alınarak 2 gruba bölünmüştür. 1 . grup kazanımlara 3 hafta, 2.grup kazanımlara ise 2 haftalık süre ayrılmıştır. 1. grup kazanımların günlük yaşam bağlamını kurmak için REACT stratejisinin her bir basamağına ilişkin birinci basamak 1 diğer basamaklarda 2'şer olmak üzere toplam 10 etkinlik planlanmıştır. Bu 10 etkinlik toplamda 1. grup kazanımların hepsini hedeflemiştir. 2. grup kazanımlar için de aynı şekilde REACT stratejisinin her bir basamağına uygun 1'er tane toplamda 5 etkinlik planlanmıştır. Toplamda REACT stratejisine uygun 15 etkinlik ile yarı deneysel işlem yürütülmüsşür. Kontrol grubu öğrencileri ile elektrik yükleri ve elektrik enerjisi ünitesinde 5 hafta süre boyunca 2018 fen bilimleri öğretim programında ve ders yıllık planında belirtildiği şekilde dersler işlenmiştir. Ders kitabında mevcut olan etkinlikler yapılmıştır. Kontrol grubunda da günlük yaşam örneklerine yer verilmiştir. Deney grubunda farklı olarak öğrenciler bir kurgu içerisinde, yaparak yaşayarak ve aktif olarak sürece dâhil olarak günlük yaşam bağlamını kurmuşlardır.

REACT Stratejisine Uygun Etkinlik Örneği:Aşağıda araştırma kapsamında kullanılan REACT stratejisine uygun bir etkinlik örneği sunulmuştur. Deney ve drama olarak planlanan iki etkinlik, 1. grup kazanımlarda REACT 
stratejisinin ikinci basamağı olan tecrübe etme (Experiencing) basamağ 1 için kullanılmıştır.

\section{Etkinlik}

Etkinlik Adı: Fabrika Bacasinda Filtreyim

Etkinlik Türü: Drama

Sinff Düzeyi: 8. sinuflar

Hedeflenen kazanımlar: "Elektrik yüklerini sinıflandırarak aynı ve farklı cins elektrik yüklerinin birbirlerine etkisini açıklar" kazanımının günlük yaşam ile bağlamını sağlamak.

Materyaller: Karton parçaları, keçeli kalemler, kurdele ve ip.

\section{Sözcükler ve Kavramlar:}

\section{Öğrenme süreci:}

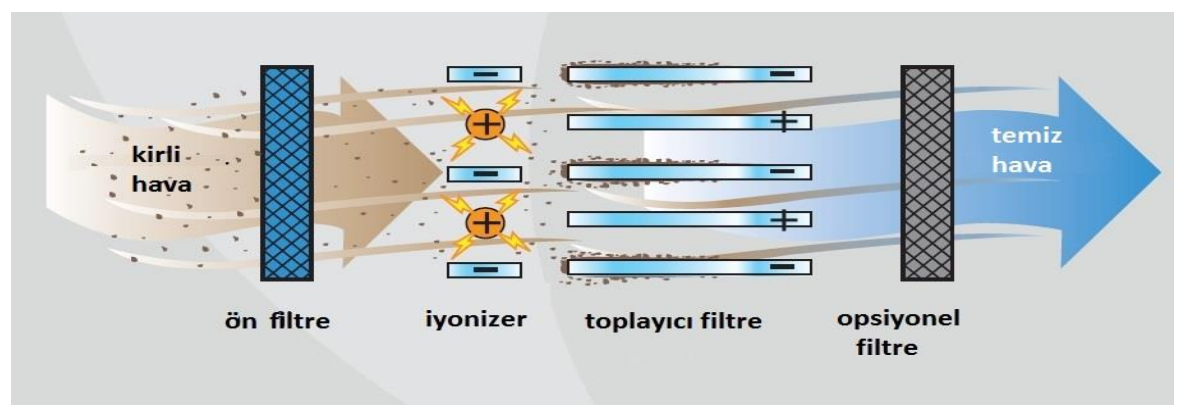

Yukarıda elektrostatik bir baca filtre sisteminin çalışma şeması verilmiştir. Kirli havayı temsilen uzun ve kısa karton parçaları ön filtreyi canland1ran iki öğrenci tarafından filtre edilir. Uzun olan karton parçaları ön filtrede kalır. Karton parçalarını öğrenciler taşımaktadır. İyonizer görevindeki öğrenciler tarafından ön filtreyi geçen karton parçalarına negatif yükler yapıştırır. Burada kirli ve temiz olan kartonları ayırt etmede kirli hava olan kartonlarda negatif yüklerin yerleşeceği girintiler olacaktır. Toplayıcı filtreler ise negatif ve pozitif yükleri taşıyan levhalardır. İyonizerden negatif yüklenerek geçen kirli hava kartonları levhalar tarafından itilip çekilerek tutulur. Böylece kirli hava temizlenmiş olur.

\section{Değerlendirme:}

- Elektrik yükleri birbirlerini nasıl etkiler? 
- Aralarında itme ve çekme kuvvelerinin uygulandığı elektrik yüklerini belirtiniz?

- Toplayı filtrelerde biriken kirli parçacıklara ne oluyor?

\section{Etkinlik}

Alüminyum Tabakların Dansı?

Ünite: 7. Sınıf Elektrik Yükleri Ve Elektrik Enerjisi Ünitesi

Konu: Elektriklenme

Araç - Gereçler: Van de graff jeneratörü, alüminyum tabaklar, bant.

Nasıl Deneyelim?

Van de graff jeneratörünün elektrik bağlantıları kurulup çalışmaya hazır hale getirilir. Alüminyum tabaklardan bir tanesi bant yardımı ile jeneratörün küresine yapıştırılır. Diğer alüminyum tabaklar ise yapıştıılan ilk tabağın üzerine birbiri üstüne içi içe geçecek şekilde dizilir ve sonrasında jeneratör çalıştırılır.

\section{Hangi Sonuçlara Vardık?}

- Deneyin sonucunda neler gözlemlediniz?

- Deney sonucunda alüminyum tabaklar birbirini nasıl etkiledi?

- Sizce tabakların birbirlerini itmesinin nedeni jeneratörün tabakları aynı elektrik yüküyle yüklemesi olabilir mi?

Günlük Hayatımızda Neler Oluyor?: Bulutlar arasındaki elektrik geçişi ile şimşek, bulutlar ile yeryüzü arasında ise yıldırım olaylarının gerçekleştiğini biliyoruz. Bu doğa olaylarını elektriklenme olayı ile nasıl ilişkilendiririz?

Petrol taşıyan tankerler hareket ederken tanker içindeki petrol de ileri geri hareket ederek deponun yüzeyi ile sürtünme sonucunda elektriklenir. Olası bir kıvılcımla patlamaların olmaması için tankerlerin arkasına bir zincir takılır. Takılan zincirin diğer ucu da asfalta değecek şekildedir. Böylece petrolün sürtünmesi ile oluşan serbest yükler toprağa akmış olur. Kışın giymiş olduğumuz kalın yünlü kazaklarla vücudumuz gün içinde sürtündüğünden vücudumuzda serbest yükler oluşur. Kazağımızı çıkarırken çıtır çıtır sesler gelir. Açığa çıkan yükler birbirine değerek nötrlenirken kıvılcım çıkarır. Eğer karanlık bir odada kazağımızı çkarırsak kıvılcımları görürüz. Fabrika bacalarından çıkan ve hava kirliliğine sebep olan gazların atmosfere 
salınımını önlemede bacalara filtre takılması gerektiğini biliyoruz. Peki, baca filtreleri nasıl çalışmaktadır?

\section{Verilerin Analizi}

Uygunluğu uzman görüşüne başvurularak oluşturulmuş REACT stratejisine uygun çalışma yaprakları hazırlanmış ve uygulanmıştır. Uygulama sonunda elde edilen veriler SPSS 21 istatistik programı ile analiz edilmiştir. Verilerin normal dağılım gösterip göstermediğini belirlemek amacıyla Shapiro-Wilk normallik testi yapılmıştır. Ayrıca verilere ilişkin çarpıklık basıklık değerlerine bakılmıştır. Çarpıklık basıklık değerlerine ilişkin Büyüköztürk (2008) +1, -1 aralığını normal dağılımdan önemli bir sapma göstermediği şeklinde kabul ederken, Tabachnick ve Fidell (2013) +1.5, -1.5 aralığını, George ve Mallery (2010) +2, -2 aralığını kabul etmektedir. Aşağıda hem deney ve kontrol grupları için ön test son test testlerinin tanımlayıc istatistik bilgileri analizleri araştırılmıştır. Araştırmadaki verilerin normal dağılım gösterip göstermediğinin bir ölçüsü olan normallik testlerinden araştırmanın örneklem büyüklüğü $N=37<50$ olduğu için shapiro wilks sonuçlarına bakılmıştır. Fen öğrenmeye yönelik öz-yeterlik ölçeği ve 21. Yüzyıl becerileri ölçeğinden deney ve kontrol grubunun ön test son test puanlarının shapiro-wilks normallik testi sonuçları incelendiğinde $\mathrm{p}$ değerleri anlamlılık düzeyi olan. 05 'ten büyük olduğu, çarpıklık basıklık değerleri kabul edilebilir aralıkda bulunduğundan verilerin normal dağılımdan aşırı sapma göstermediği düşünülmüştür. Fen Öğrenmeye Yönelik Öz-Yeterlik İnanç Ölçeği ve 21. Yüzyıl Beceri Ölçeğinden elde edilen verilerin analizinde parametrik istatistik tekniklerinden t-testi kullanılmıştır (Cameron, 2004).

Deney ve Kontrol grubunun ön test-son test 21. Yüzyıl Beceri Ölçeği ve Fen Öğrenmeye Yönelik Öz Yeterlik Ölçeği'nin alt boyutlarının puanlarına göre karşılaştırma yaparken çok değişkenli ANOVA (MANOVA) kullanılmıştır. Büyüköztürk (2008)'e göre MANOVA, bağımlı değişkenlerin bileşenlerinden elde edilen grup ortalama puanları arasında fark olup olmadığını inceleyen bir tekniktir. MANOVA, bağımlı değişken üzerinde etkisi gözlenen faktör sayısına göre de tanımlanabilir. Türkmen (2008) varyans analiziyle (ANOVA) yapılan çalışmalarda her defasında tek bir bağımlı değişken boyutunda bağımsız değişkenler açısından karşılaştırma yapılırken MANOVA testinde birden fazla bağımlı değişken aynı bağımsız değişkenler 
için varyans analizi yapma fırsatı verdiğini belirtmektedir. Böylelikle gereksiz tekrarlardan kaçınılarak bulguları tek bir tabloda sunabilme imkânını sağlanmaktadır.

Deney ve kontrol grupları arasındaki farkın anlamlılığını belirleyebilmek için p değerinin 0,05' den küçük olmasına bakılmıştır. Köklü, Büyüköztük ve Çokluk Bökeoğlu (2010)'na göre örneklemler ortalamaları arasındaki farkların anlamlı bulunması bağımsız ve bağımlı değişken arasında güçlü bir ilişki olduğunu garanti etmez. Cohen tarafından formüle edilen standardize edilmiş etki büyüklüğü indeksi olan d değeri ise karşılaştırılan ortalamaların birbirlerinden kaç standart sapma uzaklaştığını yorumlama imkânı verir. King ve Minium (2003), örnekler üzerinde açılayarak sadece p değeri dikkate alınarak yapılan çalışmalara güvenmenin mantıklı olmadığını ifade etmektedirler. Etki büyüklüğü değeri olan d'nin + sonsuz ve - sonsuz arasında değer alabildiğini, işaretine bakılmaksızın, 0,2 küçük etki büyüklüğü, 0,5 orta ve 0,8 büyük etki büyüklügü olarak yorumlandığını ifade etmektedir (Büyüköztürk, 2008; Erkuş, 2006). Bu çalışmada deney ve kontrol grupları arasındaki farkın anlamlı olduğu durumlarda etki değeri hesaplanmıştir.

\section{Bulgular}

\section{Yüzyıl Becerileri Ölçeğinden Elde Edilen Bulgular}

Öğrencilerinin ön test testinden aldıkları puanların ortalamaları hesaplanmıştır. Ortalamalar arasında istatistiksel olarak anlamlı bir fark olup olmadığı araştırılmıştır. Bu amaçla deney ve kontrol gruplarının, ön testinden aldıkları puanlara göre Grup Büyüklügü̈, Puanların Aritmetik Ortalaması ve Standart Sapmaları hesaplanmış, grupların Aritmetik Ortalamaları arasındaki farkın anlamlı olup olmadığını anlamak için $t$ testi yapılmıştır. Ön test puanları incelendiğinde çıkan sonuçlar Tablo 5'de özetlenmiştir.

Tablo 5. 21.Yüzyıl Becerileri Ölçeği İçin Deney Grubu ve Kontrol Grubu Öğrencilerin, Ön test Karşılaştırması t-Testi Sonuçları

\begin{tabular}{lllllll}
\hline Gruplar & $\mathrm{N}$ & $\mathrm{X}$ & ss & sd & $\mathrm{t}$ & $\mathrm{p}$ \\
\hline Kontrol & 17 & 102,23 & 21,72 & 35 & \multirow{2}{*}{1,87} & .069 \\
Deney & 20 & 113,75 & 15,44 & & & \\
\hline
\end{tabular}


Tablo 5'deki sonuçlara göre $\mathrm{p}=0.06$ ( $\mathrm{p}>.05)$ bulunduğundan ön test sonuçları açısından deney ve kontrol grubu öğrencileri arasında istatistiksel bir farklılık yoktur.

Deney ve kontrol grubu öğrencilerinin uygulama sonrası 21. Yüzyıl Becerilerinin Gelişimi testinden aldıkları puanlar arasında anlamlı bir farklılık olup olmadığ 1 araştırılmıştır. Deney ve kontrol grubu öğrencileri arasında ön test sonuçları açısından manidar bir farklılık olmadığından sadece deney ve kontrol grubunun son test sonuçlarının t-testi analizine bakılmıştır. Deney ve kontrol grubunun son test puanlarına ilişkin bulgular Tablo $6^{\prime}$ da verilmiştir.

Tablo 6. 21.Yüzyıl Becerileri Ölçeği İçin Deney Grubu ve Kontrol Grubu Öğrencilerin, Son Test Karşılaştırması t-Testi Sonuçları

\begin{tabular}{lllllll}
\hline Gruplar & N & $X$ & ss & sd & t & p \\
\hline Kontrol & 17 & 101 & 14,21 & \multirow{2}{*}{35} & \multirow{2}{*}{4,07} & \multirow{2}{*}{$000^{*}$} \\
Deney & 20 & 122 & 15,97 & & \\
\hline
\end{tabular}

${ }^{*} \mathrm{p}<0,05$ olduğundan fark anlamlıdır. Cohen $\mathrm{d}=1,38$, etki büyüklüğ ü ise 0,57 dir.

Deney grubu ortalama puanları kontrol grubundan daha yüksektir. Bu fark $(p=.000) p$ değeri $p<.05$ bulunduğu için istatistiksel olarak anlamlıdır.

Tablo 7. Deney ve Kontrol Grubu Öğrencilerinin 21. Yüzyıl Becerileri Ölçeği Faktörlerine Göre Ön Test MANOVA Sonuçları

\begin{tabular}{|c|c|c|c|c|c|c|}
\hline Faktör & Grup & $\mathrm{N}$ & $\begin{array}{l}\text { Aritmetik } \\
\text { Ortalama }\end{array}$ & $\begin{array}{l}\text { Standart } \\
\text { Sapma }\end{array}$ & F & $\mathrm{p}$ \\
\hline \multirow{2}{*}{ Bilişsel } & Deney & 20 & 39,15 & 6,59 & 3,67 & 0,56 \\
\hline & Kontrol & 17 & 34,00 & 9,67 & & \\
\hline \multirow{2}{*}{ Duyuşsal } & Deney & 20 & 38,95 & 5,34 & 5,23 & 0,51 \\
\hline & Kontrol & 17 & 34,29 & 7,02 & & \\
\hline \multirow{2}{*}{ Sosyo kültürel } & Deney & 20 & 35,65 & 5,36 & 0,56 & 0,45 \\
\hline & Kontrol & 17 & 33,94 & 8,34 & & \\
\hline
\end{tabular}

Tablo 7 incelendiğinde, deney ve kontrol grubu öğrencilerinin 21. Yüzyıl becerileri Ölçeği'nin bilişsel, duyuşsal ve sosyokültürel faktörlerinden aldıkları puanlara göre ön testte aralarında anlamlı bir farkın olmadığı görülmektedir. 
Tablo 8. Deney ve Kontrol Grubu Öğrencilerinin 21.Yüzyıl Becerileri Ölçeği Ölçeği Faktörlerine Göre Son Test MANOVA Sonuçlan

\begin{tabular}{lllllll}
\hline Faktör & Grup & $\mathrm{N}$ & $\begin{array}{l}\text { Aritmetik } \\
\text { Ortalama }\end{array}$ & $\begin{array}{l}\text { Standart } \\
\text { Sapma }\end{array}$ & $\mathrm{F}$ & $\mathrm{p}$ \\
\hline Bilişsel & Deney & 20 & 42,00 & 6,30 & 11,27 & $0,002^{*}$ \\
& Kontrol & 17 & 34,70 & 6,89 & & $0,003^{*}$ \\
\hline Duyuşsal & Deney & 20 & 40,80 & 8,03 & 10,61 & $0,005^{*}$ \\
& Kontrol & 17 & 33,17 & 5,79 & & 9,06 \\
\hline Sosyokültürel & Deney & 20 & 39,20 & 5,45 & & \\
& Kontrol & 17 & 33,70 & 5,62 & & \\
\hline
\end{tabular}

${ }^{*} p<0,05$ olduğundan fark anlamlıdır. Bilişsel Cohen $d=1,10$ ve etki büyüklüğü 0,48 , duyuşsal Cohen $\mathrm{d}=1,08$ ve etki büyüklüğ̈̈ 0,47 , sosyokültürel Cohen $\mathrm{d}=0,99$ ve etki büyüklüğü 0,44 olarak bulunmuştur.

Tablo 8'e göre 21. Yüzyıl becerileri ölçeği bilişsel, duyuşsal ve sosyokültürel faktörleri için deney ve kontrol grubu son testlerinde deney grubu lehine anlamlı bir farkın olduğu görülmektedir.

Tablo 9. 21.Yüzyıl Becerileri Ölçeği İçin Deney Grubu Öğrencilerin, Ön Test Son Test Karşılaştırması t-Testi Sonuçları

\begin{tabular}{lllllll}
\hline Ölçüm & $\mathrm{N}$ & $\mathrm{X}$ & $\mathrm{ss}$ & $\mathrm{sd}$ & $\mathrm{t}$ & $\mathrm{p}$ \\
\hline Ön test & 20 & 113,75 & 15,44 & \multirow{2}{*}{14,89} & \multirow{2}{*}{2,47} & \multirow{2}{*}{$023^{*}$} \\
Son test & 20 & 122 & 15,97 & & & \\
\hline
\end{tabular}

${ }^{*} p<0,05$ olduğundan fark anlamlıdır. Cohen $d=0.52$ ve etki büyüklüğü 0,25 olarak bulunmuştur.

21.Yüzyıl Becerileri Ölçeği için deney grubunun ön test son test puanları karşılaştırıldığında son testler lehine anlamlı farkın olduğu görülmektedir.

Tablo 10. 21.Yüzyıl Becerileri Ölçeği İçin Kontrol Grubu Öğrencilerin, Ön Test Son Test Karşılaştırması t-Testi Sonuçları

\begin{tabular}{lllllll}
\hline Ölçüm & $\mathrm{N}$ & $\mathrm{X}$ & $\mathrm{ss}$ & $\mathrm{sd}$ & $\mathrm{t}$ & $\mathrm{p}$ \\
\hline Ön test & 17 & 102,23 & 21,72 & \multirow{2}{*}{16,06} & \multirow{2}{*}{0,16} & \multirow{2}{*}{87} \\
Son test & 17 & 101,58 & 14,21 & & \\
\hline
\end{tabular}

21.Yüzyıl Becerileri Ölçeği için kontrol grubu öğrencilerinin ön test son test puanları karşılaştırıldığında istatistiki olarak anlamlı bir farkın olmadığı görülmektedir. 


\section{Fen Öğrenmeye Yönelik Öz-Yeterlik İnançlar Ölçeğinden Elde Edilen Bulgular}

Öğrencilerinin ön test testinden aldıkları puanların ortalamaları hesaplanmıştır. Ortalamalar arasında istatistiksel olarak anlamlı bir fark olup olmadığı araştırılmıştır. Ön test puanları incelendiğinde çıan sonuçlar Tablo 11 'de özetlenmiştir.

Tablo 11. Fen Öğrenmeye Yönelik Öz-Yeterlik İnanç Ölçeği İçin Deney Grubu ve Kontrol Grubu Öğrencilerin, Ön test Karşılaştırması t-Testi Sonuçları

\begin{tabular}{lllllll}
\hline Gruplar & $\mathrm{N}$ & $\overline{\mathrm{x}}$ & $\mathrm{ss}$ & $\mathrm{sd}$ & $\mathrm{t}$ & $\mathrm{p}$ \\
\hline Kontrol & 17 & 50,55 & 10,14 & \multirow{2}{*}{35} & \multirow{2}{*}{1,18} & \multirow{2}{*}{0,24} \\
Deney & 20 & 46,41 & 11,15 & & \multirow{2}{*}{} \\
\hline
\end{tabular}

Tablo 11'deki sonuçlara göre $\mathrm{p}=0,245$ ( $\mathrm{p}>.05$ ) bulunduğundan ön test sonuçları açısından deney ve kontrol grubu öğrencilerinin uygulama sonrası Fen Öğrenmeye Yönelik Öz-Yeterlik İnanç Ölçeğinden aldıkları puanlar arasında anlamlı bir farklılık olup olmadığı araştırılmıştır. Deney ve kontrol grubu öğrencileri arasında ön test sonuçları açısından manidar bir farklılık olmadığından sadece deney ve kontrol grubunun son test sonuçlarının ttesti analizine bakılmıştır. Deney ve kontrol grubunun son test puanlarına ilişkin bulgular Tablo 16' da verilmiştir.

Tablo 12. Fen Öğrenmeye Yönelik Öz-Yeterlik İnanç Ölçeği İçin Deney Grubu ve Kontrol Grubu Öğrencilerin, Son Test Karşılaştırması t-Testi Sonuçları

\begin{tabular}{lllllll}
\hline Gruplar & $\mathrm{N}$ & $\overline{\mathrm{x}}$ & $\mathrm{ss}$ & $\mathrm{sd}$ & $\mathrm{t}$ & $\mathrm{p}$ \\
\hline Kontrol & 17 & 44,11 & 9,6 & \multirow{2}{*}{35} & \multirow{2}{*}{3,92} &, $000^{*}$ \\
Deney & 20 & 58,35 & 12,00 & & \\
\hline
\end{tabular}

${ }^{*} \mathrm{p}<0,05$ olduğundan fark anlamlıdır. Cohen $\mathrm{d}=1,28$ ve etki büyüklüğü 0,53 olarak bulunmuştur. Deney grubu ortalama puanları kontrol grubundan daha yüksektir. Bu fark $(\mathrm{p}=.000) \mathrm{p}$ değeri $\mathrm{p}<.05$ bulunduğu için istatistiksel olarak anlamlıdır.

Tablo 13. Fen Öğrenmeye Yönelik Öz-Yeterlik İnanç Ölçeği İçin Deney Grubu Öğrencilerin, Ön Test Son Test Karşılaştırması t-Testi Sonuçları

\begin{tabular}{lllllll}
\hline Ölçüm & $\mathrm{N}$ & $\mathrm{X}$ & ss & sd & $\mathrm{t}$ & $\mathrm{p}$ \\
\hline Ön test & 20 & 50,55 & 10,14 & 19 & 3,6 & $.002^{*}$ \\
Son test & 20 & 58,35 & 12,00 & & \\
\hline
\end{tabular}

${ }^{*} \mathrm{p}<0,05$ olduğundan fark anlamlıdır. Cohen $\mathrm{d}=0,70$ ve etki büyüklüğü 0,33 olarak bulunmuştur. 
Deney grubu öğrencilerinin Fen Öğrenmeye Yönelik Öz-Yeterlik ölçeği ön test son test puanları karşılaştırıldığında son test puanları lehine anlamlı farklılık vardır.

Tablo 18. Fen Öğrenmeye Yönelik Öz-Yeterlik İnanç Ölçeği İçin Kontrol Grubu Öğrencilerin, Ön Test Son Test Karşılaştırması t-Testi Sonuçlarn

\begin{tabular}{lllllll}
\hline Ölçüm & $\mathrm{N}$ & $\mathrm{X}$ & $\mathrm{ss}$ & $\mathrm{sd}$ & $\mathrm{t}$ & $\mathrm{p}$ \\
\hline Ön test & 17 & 46,41 & 11,15 & \multirow{2}{*}{16} & \multirow{2}{*}{1,2} & \multirow{2}{*}{87} \\
Son test & 17 & 44,11 & 9,6 & & \multirow{2}{*}{} \\
\hline
\end{tabular}

Kontrol grubu öğrencilerinin Fen Öğrenmeye Yönelik Öz-Yeterlik ölçeği ön test son test puanları arasında istatistiki olarak anlamlı fark olmadığı görülmektedir.

Tablo 14. Deney ve Kontrol Grubu Öğrencilerinin Fen Öğrenmeye Yönelik Öz-Yeterlik Inanç Ölçeği Faktörlerine Göre Ön Test MANOVA Sonuçlarn

\begin{tabular}{|c|c|c|c|c|c|c|}
\hline Faktör & Grup & $\mathrm{N}$ & $\begin{array}{l}\text { Aritmetik } \\
\text { Ortalama }\end{array}$ & $\begin{array}{l}\text { Standart } \\
\text { Sapma }\end{array}$ & $\mathrm{F}$ & $\mathrm{p}$ \\
\hline Bireysel Başarıya Yönelik Özyeterlik & Deney & 20 & 12,70 & 3,37 & 0,27 & 0,60 \\
\hline Boyutu & Kontrol & 17 & 13,29 & 3,47 & & \\
\hline Sonuca Yönelik Özyeterlik & Deney & 20 & 9,35 & 2,30 & 0,34 & 0,56 \\
\hline Boyutu & Kontrol & 17 & 8,88 & 2,57 & & \\
\hline Fen Öğrenmeye Yönelik Özyeterlik & Deney & 20 & 28,50 & 5,78 & 4,09 & 0,51 \\
\hline Boyutu & Kontrol & 17 & 24,23 & 7,04 & & \\
\hline
\end{tabular}

$p>0,05$

Deney ve Kontrol grubu öğrencilerinin Fen Öğrenmeye Yönelik ÖzYeterlik İnanç ölçeği faktörlerine göre ön testleri incelendiğinde tüm faktörlerde istatistiksel olarak anlamlı fark olmadığı görülmektedir.

Tablo 15. Deney ve Kontrol Grubu Öğrencilerinin Fen Öğrenmeye Yönelik Öz-Yeterlik İnanç Ölçeği Faktörlerine Göre Son Test MANOVA Sonuçları

\begin{tabular}{lllllll}
\hline Faktör & Grup & $\mathrm{N}$ & $\begin{array}{c}\text { Aritmetik } \\
\text { Ortalama }\end{array}$ & $\begin{array}{c}\text { Standart } \\
\text { Sapma }\end{array}$ & $\mathrm{F}$ & $\mathrm{p}$ \\
\hline $\begin{array}{l}\text { Bireysel Başarıya Yönelik Özyeterlik } \\
\text { Boyutu }\end{array}$ & Deney & 20 & 14,30 & 7,26 & 8,50 & $0,00^{*}$ \\
\hline & Kontrol & 17 & 11,23 & 6,10 & & \\
\hline $\begin{array}{l}\text { Sonuca Yönelik Özyeterlik } \\
\text { Boyutu }\end{array}$ & Deney & 20 & 10,30 & 2,38 & & \\
\hline Ken Öğrenmeye Yönelik Özyeterlik & Kontrol & 17 & 7,76 & 2,30 & 10,69 & $0,006^{*}$ \\
Boyutu & Deney & 20 & 33,75 & 7,26 & 14,98 & $0,002^{*}$ \\
\cline { 2 - 7 } & Kontrol & 17 & 25,11 & 6,10 & & \\
\hline
\end{tabular}

* $\mathrm{p}<0,05$ olduğundan fark anlamlıdır. Bireysel başarıya yönelik öz yeterlik Cohen $\mathrm{d}=0,45$ ve etki büyüklüğü 0,22 , sonuca yönelik öz yeterlik Cohen $d=1,08$ ve etki büyüklüğü 0,47 , fen öğrenmeye yönelik öz yeterlik Cohen $\mathrm{d}=1,28$ ve etki büyüklüğü 0,54 olarak bulunmuştur. 
Deney ve kontrol grubu öğrencilerinin Fen Öğrenmeye Yönelik ÖzYeterlik İnanç Ölçeği faktörlerine göre son test puanları karşılaştırıldığında bireysel başarıya yönelik özyeterlik boyutu, sonuca yönelik öz yeterlik boyutu ve fen öğrenmeye yönelik öz yeterlik boyutlarında deney grubu lehine anlamlı farklılık olduğu görülmektedir.

\section{Sonuç ve Tartışma}

Bu çalışmada REACT stratejisinin 8. sınıf öğrencilerinin elektrik yükleri ünitesindeki 21. Yüzyıl becerilerine ile fen öğrenmeye yönelik öz yeterlilik inançlarına etkisi araştırılmıştır. Ülkemizdeki vatandaşların fen bilimleri okuryazarı olarak yetişmesini hedefleyen fen bilimleri dersi öğretim programının; dünyayı anlamak, merak duygusunu geliştirmek, fen toplum ve çevre etkileşiminin anlaşılmasını sağlamak, meslek seçimine yardımcı olmak, alışılmışın dişında kalan durumlara uyum sağlayabilme, bilinçli kararlar verebilmek ve her konuda verimliliği artırabilmek gibi amaçları vardır.

Fen eğitimi uygulamaları bilimsel anlamda okuryazar bir nüfusun var olmasını, öğretmen ve öğrencilerin bilim öğrenmeye odaklanmış olmalarını amaçlar. Öğrencilere verilen eğitim eğer öğrencileri eğitimin belirtilen amaçlarına ulaştırıyorsa başarılı olunmuştur. Başarıyı da süreçte hangi yöntemin seçilecek olması etkiler. Diğer ülkelerdeki yapılandırmacı öğrenme yaklaşımının başarıya ulaşması ülkemizdeki fen bilimleri öğretim programını da etkilemiş ve ülkemizde bu ulusal eğilimden hareketle yapılandırmacı öğrenme yaklaşımın benimsendiği görülmektedir (Ayaz ve Şekerci, 2015). Öğrencilerin fikir ve düşüncelerini rahatça ifade edebilmelerine imkân sağlayan (Cirit Gül, Apaydın, Omca Çobanoğlu ve Tağrikulu, 2018) ve günlük yaşam bağlamını kuran öğretim yöntemlerinin (Derman ve Badeli, 2017; Korsacılar ve Çalışkan, 2015) seçilmesi verimli bir öğretim yapılması büyük önem taşımaktadır. Elektrik konusu fen bilimleri dersinin temel alnlarından biridir. Elektrik kavramının günlük hayattaki kullanımı ile derslerdeki elektrik kavramları arasında büyük fark vardır (Yılmaz ve Çavaş, 2006). Bu nedenle öğretmenin öğretim sürecini yakından uzağa olacak şekilde günlük yaşam bağlamını kurarak planlaması gerekmektedir. Gerçek yaşamla ilişki kurularak yapılan etkinlikler konuyu daha açık ve anlaşlır hale getirmektedir (Hırça, 2012). Bağlam temelli yaklaşımla hazırlanan materyaller öğrencilerin kavramsal başarılarını arttırmakta ve onların aktif öğrenmesine katkı sağlamaktadır 
(Tekbıyık, 2010). Öğrencilerin günlük yaşam bağlamını süreçte aktif rol alarak kurmaları onlara bir yaşantı deneyimi sağlamıştır. Böylece öğrecilerin özyeterlilik inançlarının ve 21. Yüzyıl becerilerinin geliştirilmesi hedeflenmiştir.

REACT stratejisinin 8. sinıf öğrencilerinin elektrik yükleri ünitesindeki 21. Yüzyıl becerilerine ile fen öğrenmeye yönelik öz yeterlilik inançlarına etkisinin araştırıldığı bu çalışmada deney ve kontrol gurubu öğrencileri arasında istatistiksel olarak anlamlı bir fark bulunmuştur. Elde edilen veriler bize REACT stratejisinin etkili olduğunu göstermektedir. Benzer şekilde; Kirman Bilgin (2015) maddenin yapısı ve özellikleri ünitesinde, Sevinç (2015) asitler ve bazlar konusunda Kirman, Bilgin ve Yiğit (2017) yine maddenin tanecikli yapısı konusunda, Keskin ve Çam (2019) akademik başarısında ve fen okuryazarlık düzeyine etkisini, Ayvacı, Nas ve Dilber (2016) 6. sınıflar iletken ve yalıtkan maddeler konusunda REACT stratejisinin etkisini araştıran çalışmalar yapmışlar ve sonuç olarak REACT stratejisinin öğrencilerin başarılarına, fen okuryazarlık düzeyine, tutumlarına, günlük yaşam bağlamını kurmalarına, fen öğrenmeye yönelik motivasyonlarına ve tutumlarına olumlu etkilerinin olduğunu bulmuşlardır. 21. Yüzyıl becerileri ölçeğinin bilişsel, duyuşsal ve sosyokültürel alt boyutlardan oluştuğu dikkate alındığında alan yazında yer alan REACT'ın bilişsel ve duyuşsal boyutlardaki değişkenlere olumlu etkisinin REACT stratejisinin öğrencilerin 21. Yüzyıl becerilerine etkisinin olumlu olmasıyla açıklanabilir. Ayrıca REACT'ın fen öğrenmeye yönelik öz yeterlilik inançlarına olumlu etkisi olduğu sonucuna ulaşılmıştır.

\section{Öneriler}

Yaşam temelli öğretimin etkinliğinin daha fazla nasıl artırlabileceği konusunda ortaokul seviyesinde ilave çalş̧malara ihtiyaç olduğu düşünülmektedir. Ortaokul seviyesinde az sayıda çalışma yapıldığı göz önünde bulundurulursa farklı sınıf seviyelerinde ve farklı ünitelerde REACT stratejisinin etkileri araştırılabilir. Bu araştırmanın sonuçları doğrultusunda REACT stratejisinin olumlu etkisinin olduğu göz önünde alınarak öğrencilerin 21. yüzyıl becerilerini ve fen bilimlerine yönelik öz yeterlik inançlarını geliştirmede REACT stratejisinden faydalanılabilir. REACT stratejisi ile kurulan günlük yaşam bağlamı öğrencilerde olumlu bir şekilde sonuç alabileceklerine dair inançları$\mathrm{n} ı$ artırmaktadır. Bu nedenle öğrencilerin fen öğrenmeye, bireysel başarıya ve sonuca yönelik özyeterlilik inançlarının artırılmasında REACT stretejisi kulla- 
nılabilir. 21. yüzyıl becerilerinin alt boyutları olan bilişsel, duyuşsal ve sosyakültürel alt boyutlarınının geliştirilmesinde REACT etkinlikleri kullanılabilir çünkü; bu çalışma sorumluluk, bilginin yapılandırılması ve takım çalışması gibi bu alt boyutları geliştiren etkinlikleri içermektedir. REACT stratejisinin ögrencilerdeki diğer beceri alanlarına etkileri araştırılabilir. Yapılan bu nicel çalışma nitel boyutlu çalışmalar ile beraber yürütülüp farklı etkileri ortaya çıkartılabilir. 


\title{
EXTENDED ABSTRACT
}

\section{React's Effects In Science Teaching: 21st Century Skills And Science Self-Efficiency Beliefs}

\author{
Huriye Deniş Çeliker - Muhammed Kara \\ Burdur Mehmet Akif Ersoy University, Elmalı Ömerpaşa Middle School
}

\begin{abstract}
Despite advances in technology and science, issues such as climate change, loss of biodiversity, competition for energy resources, access to clean water, air pollution and land degradation continue to be major challenges and problems for countries. Providing new developments in science and technology and producing solutions to existing problems is possible with education. Education should reveal a new approach in this sense. In this approach, the context students will establish with real life is very important. Learning technologies, learning environments and student needs change frequently. Students, on the other hand, need to be prepared to live in conditions that can always change in the 21st century as future citizens. In real education, a student uses what they learn at school to apply them in their daily life and solve problems faced from different angles. Teachers, on the other hand, should establish connections between new developments and daily life and increase students' access to science. It is possible for students to realize why they need to learn a subject with the context to be established with daily life. Students will be successful if they can explain the situations they encounter with scientific concepts. Contemporary science practices are based on constructivist thinking. Context-based learning is also based on constructivist approach. Context-based learning establishes relationships based on daily life examples. This aspect differs from other theories. Context-based learning has been explained on various projects with the Vocational Research and Development Center (CORD) group, which is a change in education in America. The methods used by teachers who were successful in their field and made a difference in their classrooms were investigated, and the strategy of Associating, Experiencing, Implementing, Collaborating and Transferring, in short, REACT, emerged in five steps. A training planned according to the REACT stra-
\end{abstract}


tegy will enable them to establish the context of daily life. It is thought that this helps the development of self-efficacy perceptions and 21st century skills towards learning science. It is aimed that REACT, which is one of the context-based learning strategies in 8th grade electrical loads and electrical unit, has an effect on 21st century skills and self-efficacy beliefs for science learning. In this study, in which the effects of REACT strategy, which is an application area of context-based learning, in developing students' selfefficacy beliefs for science learning and 21st century skills, a pre-test-posttest model was used with groups that were not equated from quasiexperimental designs. Quasi-experimental designs are the most commonly used experimental design when it is not possible to control all variables. A total of 2 branch 8 th grade students in the study are students in preformed classes. Therefore, it was not possible for students to be randomly assigned to the experimental and control groups. One of the classes was determined as a random experiment and the other as the control group. The sample of the study consists of 37 8th grade students from a secondary school. Since the sample consists of a wide variety of socio-cultural levels, it was considered appropriate to conduct the study on this sample. Due to problems such as time, money and labor, the sample was wanted to be feasible and applicable. Appropriate sampling method was applied in the research. The 21st century skills scale and the self-efficacy belief scale for learning science were used as data collection tools. Activities in accordance with the REACT strategy were applied in the experimental group. Lessons were conducted with the control group students within the framework of the 2018 science course curriculum. In the study, the 21st Century Skills Scale, developed by Kang, Kim, Kim, and You and adapted into Turkish by Karakaş, was used as a measuring tool. There are 33 unique items in the scale. These items consist of three main dimensions (cognitive, affective and sociocultural) and 21 sub-dimensions. The other scale used in the study (self-efficacy belief scale for learning science) was adapted by Yaman. The scale consists of 3 dimensions. The grades in the Likert type measurement tool are in the format of "Strongly disagree" and "Strongly agree". In scoring the grades of the items, scoring from negative to positive was done from 1 to 5 .It has been accepted that the measurement range is between 1.00 and 5.00, and as the scores approach 5.00, the self-efficacy belief levels for teaching are high. It has been accepted that 
scores approaching 1.00 are low. The data obtained at the end of the application were analyzed with a statistical program. The Shapiro-Wilk normality test was used to determine whether the data were normally distributed. It was found that the data showed normal distribution. According to the scores obtained from the cognitive, affective and sociocultural factors of the 21st Century Skills Scale, it is seen that there is no significant difference between them in the pre-test. When the pre-test post-test scores of the control group students are compared for the 21st Century Skills Scale, it is seen that there is no statistically significant difference. In the experimental group, the increase between the post-test and pre-test scores was found to be statistically significant. It has been investigated whether there is a significant difference between the scores of the students from the SelfEfficacy Belief Scale for Learning Science. Since there was no significant difference between the experimental and control group students in terms of pre-test results, only the t-test analysis of the post-test results of the experimental and control groups was examined. When the posttest scores of the experimental and control group students according to the SelfEfficacy Beliefs towards Learning Science Scale factors are compared, it is seen that there is a significant difference in favor of the experimental group. This difference was seen in the dimensions of individual achievement, outcome and self-efficacy for learning science. As a result, no significant difference was found in the pretests of the experimental and control groups. In the post-tests, a significant difference was found in favor of the experimental group in "21st century skills" and "self-efficacy beliefs towards science". The data obtained show us that the REACT strategy is effective. There are similar studies in terms of results in the literature. It is thought that additional studies are needed at secondary school level on how to increase the effectiveness of life-based education further.

\section{Kaynakça / References}

Acar, T. ve Öğretmen, T. (2012). Çok düzeyli istatistiksel yöntemler ile 2006 PISA fen bilimleri performansmun incelenmesi. Ë̆itim ve Bilim Dergisi, 37(163), 178-189.

Arslan, A. (2012). İlköğretim öğrencilerinin öz yeterlik inanc kaynaklarını öğrenme ve performansla ilgili öz yeterlik inancını yordama gücü. Kuram ve Uygulamada Eğitim Bilimleri, 12(3), 1907-1920. 
Ateş, S., ve Polat, M. (2005). Elektrik Devreleri Konusundaki Kavram Yanulgilarının Giderilmesinde Öğrenme Evreleri Metodunun Giderilmesi. Hacettepe Eğitim Fakültesi Dergisi, 28, 39-47.

Ayaz, M. ve Şekerci, H. (2015). Yapılandırmacı öğrenme yaklaşımının akademik başarıya ve tutuma etkisi: bir meta-analiz çalışması. Hasan Ali Yücel Ĕ̈̆itim Fakültesi Dergisi, 12-2 (24), 27-44.

Aydoğdu, B. ve Ergin, Ö. (2009). Fen ve teknoloji dersi “Yaşamımızdaki Elektrik” ünitesine yönelik bilimsel süreç becerileri ölçeğinin geliştirilmesi, E-Journal of New World Sciences Academy, 4(2), 296-316.

Aydoğdu, B., ve Ergin, Ö. (2008). Fen ve teknoloji dersinde kullanılan farklı deney tekniklerinin öğrencilerin bilimsel süreç becerilerine etkileri. Ege Eğitim Dergisi, 9(2), 15-36.

Aykutlu, I., ve Şen, A. İ. (2012). Üç aşamalı test, kavram haritası ve analoji kullanılarak lise öğrencilerinin elektrik akımı konusundaki kavram yanılgilarının belirlenmesi. Eğitim ve Bilim, 37(166), 275-288.

Aymen Peker, E., Tas, E., Apaydin, Z., ve Akman, E. (2014). Fen ve teknoloji dersi yasamimizdaki elektrik unitesi icin dusunme ajandasi (ogrenci gunlugu) tutulmasi ve tutulan ajandalarin ogrencilerin akademik basarisi uzerindeki etkileri. International Journal of New Trends in Arts, Sports \& Science Education, 3(3), 8-27.

Ayvacı, H. Ş., ve İpek Akbulut, H. (2012). Elektrik akımı ile ilgili kavramların gelişiminde $\mathrm{V}$ diyagramlarınn etkisini belirlemeye yönelik bir pilot çalışma. Erzincan Üniversitesi Eğitim Fakültesi Dergisi, 14(1), 109-126.

Ayvacı, H. Ş., Er Nas, S. ve Dilber, Y. (2016). Bağlam temelli rehber materyallerin öğrencilerin kavramsal anlamaları üzerine etkisi: "iletken ve yalıtkan maddeler" örneği. Yüzüncü Yal Üniversitesi Eğitim Fakültesi Dergisi, 13(1), 51-78.

Ayvacı, H. Ş. ve Bilge, E. (2018). Ortaöğretim öğrencilerinin günlük yaşam problemlerine alan bilgisi ile bağlam kurabilme becerilerinin değerlendirilmesi. Amasya Üniversitesi Ë̆itim Fakültesi Dergisi 7(2), 311-342.

Bandura, A. (1977). Self-efficacy: Toward a unifyingtheory of behavioral change. Psychological Review,84, 191-215.

Bennett, J., Hogarth, S., ve Lubben, F. (2003). A systematic review of the effects of context-based and Science-Technology-Society (STS) approaches in the teaching of secondary science. EPPI-Centre, Social Science Research Unit, Institute of Education, University of London.

Bozat, Ö., ve Yıldız, A. (2015). The impact of letter as one of the writing to learn activities on achievement at fifth grade electricity in our life unit. Education Sciences, 10(4), 291-304. 
Böke, K. (2009). Sosyal bilimlerde araştırma yöntemleri. İstanbul: Alfa Yayınları.

Brown, L. M. (2019). Today's demands on education. Diverse Learning Opportunities Through Technology-Based Curriculum Design içinde (s. 42-68). IGI Global.

Büyüköztürk, Ş. (2007). Deneysel desenler öntest-sontest kontrol grubu desen ve veri analizi. Ankarara: Pegem Akademi Yayıncllk.

Büyüköztürk, Ș. (2008). Sosyal bilimler için veri analizi el kitabı. Ankara: Pegem A Yayıncllk (9. bask1).

Castro, R. (2019). Blended learning in higher education: Trends and capabilities. Education and Information Technologies, 24(4), 2523-2546.

Cirit Gül, A., Apaydın, Z., Omca Çobanoğlu, E., ve Tağrikulu, P. (2018). Fen Öğretiminde Toulmin Argümantasyon Modelinin sınıf dışı (outdoor) eğitim süreci ile bütünleştirilmesi: Örnek etkinlikler. Türkiye Bilimsel Araştırmalar Dergisi, 3 (2), 103-120.

Cohen, L., Manion, L. ve Morrison, K. (2000). Research method in education. (5. Baskı) Londra: Routhledge Falmer Yayinevi.

Coştu, S. (2009). Matematik öğretiminde bağlamsal öğrenme ve öğretme yaklaşımina göre tasarlanan ögrenme ortamlarnda öğretmen deneyimleri. Yayımlanmamış yüksek lisans tezi, Karadeniz Teknik Üniversitesi, Fen Bilimleri Enstitüsü: Trabzon.

CORD, (1999). Teaching science contextually. Waco, Texas, USA: CORD Communications, Inc.

Crawford, M. L. (2001). Teaching contextually: Research, rationale, and techniques for improving student motivation and achievement in mathematics and science. Waco, Texas: CCI Publishing.

Creswell, J.W. (2003). Research design. Second edition. London: Sage publications.

Çepni, S. (Ed.). (2016). PISA ve TIMSS mantı̆̆̆n ve sorularnm anlama. Pegem Akademi.

Daşdemir, İ., ve Doymuş, K. (2012). 8. sinf kuvvet ve hareket ünitesinde animasyon kullanımının öğrencilerin akademik başarılarına, öğrenilen bilgilerin kalıcllğına ve bilimsel süreç becerilerine etkisi. Ĕgitim ve Öğretim Araştırmalan Dergisi, 1(1), 77-87.

Demirci, N., ve Yağcı, Z. (2008). Fen bilgisi dersi "yaşammızı yönlendiren elektrik" ünitesinin çoklu zekâ kuramı etkinliklerine göre değerlendirilmesi. Eğitimde Kuram ve Uygulama, 4(1),79-97.

Demircioğlu, H., Bektaş, F. ve Demircioğlu, G. (2018). Sivıların özellikleri konusunun bağlam temelli yaklaşımla öğretiminin öğrenci başarısı üzerindeki etkisi. Dicle Üniversitesi Ziya Gökalp Eğitim Fakültesi Dergisi, 33, 13-25. 
Demircioğlu, G., Kurnaz, B. ve Erol, T. (2017). Bağlam temelli yaklaşımın lise öğrencilerinin gazlar konusunu anlamaları üzerine etkisi. Eğitim ve Öğretim Araştırmalan Dergisi, 6(3), 161-174.

Demircioğlu, H., Vural, S., ve Demircioğlu, G. (2012). “REACT” stratejisine uygun hazırlanan materyalin üstün yetenekli ögrencilerin başarısı üzerine etkisi. Ondokuz Mayıs Üniversitesi Eğitim Fakültesi Dergisi, 31(2), 101-144.

Değirmenci, S., ve Karamustafaoğlu, S. (2019). Kitap incelemesi: PISA ve TIMSS mantiğini ve sorularini anlama. Elementary Education Online, 18(2), 3-8.

Derman, A. ve Badeli, Ö. (2017). İlkokul 4. Sınuf "saf madde ve karışım" konusunun öğretiminde 5e modeli ile desteklenen bağlam temelli öğretim yönteminin öğrencilerin kavramsal anlamalarına ve fene yönelik tutumlarına etkisinin incelenmesi. Abant İzzet Baysal Üniversitesi Ë̆itim Fakültesi Dergisi, 17(4), 18601881.

Dewi, D. P., Nurfajar, A. A., ve Dardiri, A. (2019, January). Creating entrepreneurship mindset based on culture and creative industry in challenges of the 21st century vocational education. 2nd International Conference on Vocational Education and Training (ICOVET 2018). Atlantis Press.

Dilber, R., ve Düzgün, B. (2003a). Doğru akm devreleri ile ilgili olarak orta öğretim fen kolu öğrencilerindeoluşan kavram yanılgıları. Çukurova Üniversitesi, Eğitim Fakültesi Dergisi, 2, 90-96.

Dilber, R., ve Düzgün, B. (2003b). Lise öğrencilerinin basit elektrik devreleri hakknndaki kavram yanılgıları üzerine bir çalışma. FÜ Fen ve Mühendislik Bilimleri Dergisi, 15(3), 349-358.

Dori, Y. J., Avargil, S., Kohen, Z., ve Saar, L. (2018). Context-based learning and metacognitive prompts for enhancing scientific text comprehension. International Journal of Science Education, 40(10), 1198-1220.

Duit, R, ve von Rhöneck, C. (1997). Learning and understanding key concepts of electricity. Connecting research in physics education with teacher education, 1, 1-6.

Erkuş, A. (2006). Sınıf öğretmenleri için ölçme ve değerlendirme: Kavramlar ve uygulamalar. Ankara: Ekinoks Yaymlar.

Eş, H., ve Sarıkaya, M. (2010). İlköğretim 6. snuf fen ve teknoloji dersi “yaşamımızdaki elektrik" ünitesinde öğrenci başarılarının incelenmesi (s. 107-127). Yüzüncü Yll Üniversitesi Ĕ̆itim Fakültesi Dergisi, 7(1), 107-127.

George, D., ve Mallery, M. (2010). SPSS for windows step by step: A simple guide and reference, 17.0 update (10a ed.) Boston: Pearson. 
Göçmençelebi, Ş. İ. (2002). Elektrik ünitesi'ndeki bilgi ve kavramlarn ilköğretim dördüncü ve beşinci sınıf öğrencileri tarafindan anlaşılma düzeyi. Yayınlanmamış Yüksek Lisans Tezi, Uludağ ÜniversitesiSosyal Bilimler Enstitüsü, Bursa.

Gül, Ş, Gürbüzoğlu-Yalmancı, S. ve Yalmancı, E. (2017). Boşaltım sistemi konusunun öğretiminde REACT stratejisinin etkisi. Kastamonu Eğitim Dergisi, 25(1),79-96.

Gürbüz, F., Turgut, Ü., ve Salar, R. (2013). 7E modelinin 6. sinff fen ve teknoloji dersi "yaşamımızdaki elektrik" ünitesinde akademik başarı ve kalıclığa etkisi. Türk Fen Ĕ̈itimi Dergisi, 10(3), 80-94.

Hırça, N. (2012). Bağlam temelli öğrenme yaklaşımına uygun etkinliklerin öğrencilerin fizik konularını anlamasına ve fizik dersine karşı tutumuna etkisi/the effects of hands on activities depend on context-based learning approach on understanding of physics and attitudes. Mustafa Kemal Üniversitesi Sosyal Bilimler Enstitüsü Dergisi, 9(17).

Hokayem, H., ve Jin, H. (2019). Enhancing environmental literacy in k-12 science classrooms. EURASIA Journal of Mathematics, Science and Technology Education, 15(6).

Holbrook, J. (2010). Education through science as a motivational innovation for science education for all. Science Education International, 21(2), 80-91.

Jinks, J., ve Lorsbach, A. (2003). Introduction: Motivation and self-efficacy belief. Reading EWriting Quarterly, 19(2), 113-118.

Kaptan, F., ve Korkmaz, H. (1999). Fen öğretimi. MEB-UINICEF Projesi Etkin Öğrenme Öğretme Öğretmen El Kitabl.

Karakaş, M. (2015). Ortaokul sekizinci stnı öğrencilerinin fen bilimlerine yönelik 21. yüzyıl beceri düzeylerinin ölçülmesi. Yayımlanmamış yüksek lisans tezi. Eskişehir Osmangazi Üniversitesi, Eğitim Bilimleri Enstitüsü: Eskişehir.

Karakuyu, Y., ve Tüysüz, C. (2011). Elektrik konusunda kavram yanılgiları ve kavramsal değişim yaklaşımı. Gaziantep Üniversitesi Sosyal Bilimler Dergisi, 10(2), 867 890.

Karsl, F. ve Yiğit, M. (2015). Lise 12. sinif öğrencilerinin alkanlar konusundaki kavramsal anlamalarina bağlam temelli öğrenme yaklaşiminin etkisi. İnönü Üniversitesi Ĕ̈itim Fakültesi Dergisi, 16(1), 43-62.

Keser, Ö. F., ve Başak, M. H. (2013). Yaşammmıdaki elektrik ünitesine yönelik öğrenci kazanim düzeylerinin incelenmesi. Journal of Turkish Science Education, 10(2), 116-137.

Keskin, F., ve Çam, A. (2019). Yaşam temelli react stratejisinin altıncı sınıf öğrencilerinin akademik başarısına ve fen okuryazarlığına etkisi. Mehmet Akif Ersoy Üniversitesi Eğitim Fakültesi Dergisi, 49, 38-59. 
King, D., ve Henderson, S. (2018). Context-based learning in the middle years: achieving resonance between the real-world field and environmental science concepts. International Journal of Science Education, 40(10), 1221-1238.

King, B. M., ve Minium, E. W. (2003). Statistical reasoning in psychology and education. New York, NY: Wiley.

Kirman Bilgin, A. (2015). Maddenin yapısı ve özellikleri ünitesi kapsammnda REACT stratejisine yönelik tasarlanan öğretim materyallerinin etkililiğinin değerlendirilmesi. Yayınlanmamış doktora tezi, Karadeniz Teknik Üniversitesi, Trabzon.

Kirman Bilgin, A., ve Yiğit, N. (2017a). Öğrencilerin" maddenin tanecikli yapısı" konusu ile bağlamları ilişkilendirme durumlarınn incelenmesi. Mersin Üniversitesi Eğitim Fakültesi Dergisi, 13(1), 303-322.

Kirman Bilgin, A., ve Yiğit, N. (2017b). REACT stratejisine yönelik tasarlanan öğretim materyallerinin öğrencilerin "yoğunluk" kavramı ile bağlamları ilişkilendirmeleri üzerine etkisinin incelenmesi. Uludağ Üniversitesi Eğitim Fakültesi Dergisi, 30(2), 495-519.

Korsacilar, S. ve Çallşkan, S. (2015). Yaşam temelli öğretim ve öğrenme istasyonları yönteminin 9. sınf fizik ders başarısı ve kalıclığa etkileri. Mersin Üniversitesi Ĕ̆itim Fakültesi Dergisi, 11(2), 385-403.

Köklü, N., Büyüköztürk, Ş., ve Çokluk Bökeoğlu, Ö. (2010). Sosyal bilimler için istatistik. Ankara: PegemA Yayınları.

Küçük, Z., ve Çalık, M. (2015). Zenginleştirilmiş 5 E modelinin yedinci snnf öğrencilerinin kavramsal değişimine etkisi: Elektrik akımı örneği. Adryaman Üniversitesi Eğitim Bilimleri Dergisi. 5(1), 1-28.

Küçüközer, H. (2003), Lise I öğrencilerinin basit elektrik devreleri konusuyla ilgili kavram yanılgiları. Hacettepe Üniversitesi Eğitim Fakültesi Dergisi, 25, 142-148.

Millar, R. ve King, T. (1993). Students" understanding of voltage in simple series electric circuits. International Journal of Science Education, 15(3), 339-349.

Mioto, F., Petri, G., von Wangenheim, C. G., Borgatto, A. F., ve Pacheco, L. H. M. (2019). bASES21-Um Modelo para a Autoavaliação de Habilidades do Século XXI no Contexto do Ensino de Computação na Educação Básica. Revista Brasileira de Informática na Educação, 27(01), 26.

Okcu, B., ve Sözbilir, M. (2016). 8. sınıf görme engelli öğrencilere "Yaşammmzdaki Elektrik" ünitesinde "Elektrik Motoru Yapalım" etkinliği. Çukurova Üniversitesi Eğitim Fakültesi Dergisi, 45(1), 23-48. 
Taş, U. E., Anıcı, Ö., Özarkan, H. B. ve Özgürlük, B. (2016). PISA 2015 ulusal raporu. Ankara: Milli Eğitim Bakanlığı. http://pisa.meb.gov.tr/wpcontent/uploads/2016/12/PISA2015_Ulusal_Rapor1.p $\mathrm{df}$ adresinden alind.

Tekbıyık, A. (2010). Bağlam temelli yaklaşımla ortaöğretim 9. sınıf enerji ünitesine yönelik 5E modeline uygun ders materyallerinin geliştirilmesi. Institute of Science, Trabzon.

Türkmen, L. (2008). Sınıf öğretmenliği programında öğrenim gören birinci sınıf düzeyinden dördüncü sınıf düzeyine gelen öğretmen adaylarının fen bilimlerine ve öğretimine yönelik tutumları. G. Ü. Kastamonu Ĕ̈itim Dergisi, 16 (1), 91-106.

Potter, N. M., \& Overton, T. L. (2006). Chemistry in sport: context-based e-learning in chemistry. Chemistry Education Research and Practice, 7(3), 195-202.

Rojewski, J. W., \& Hill, R. B. (2017). A framework for 21st-century career-technical and workforce education curricula. Peabody Journal of Education, 92(2), 180-191.

Royce, C. A. (2019). NSTA's 75th: A beginning, present, and future connected by the need for science education. Science Scope, 42(5), 5.

Sevinç, B. (2015). Asitler ve bazlar konusunda REACT stratejisine göre materyallerin geliştirilmesi ve etkililiğinin araştırılması. Doktora Tezi, Karadeniz Teknik Üniversitesi, Trabzon

Silber-Varod, V., Eshet-Alkalai, Y., ve Geri, N. (2019). Tracing research trends of 21stcentury learning skills. British Journal of Educational Technology, 50(6), 3099-3118.

Suryaningtyas, B., ve Halimah, L. (2017). The Influence of React Strategy (Relating, Experiencing, Applying, Cooperating, and Transferring) on the Ability of Mathematical Connection 5th Grade Elementary School Students. Jurnal Khazanah Sekolah Dasar, 5(1), 90-98.

Tabachnick, B., ve Fidell, L. (2013). Using multivariate statistics (sixth ed.) Pearson, Boston.

Taber, K. S. (2016). Constructivism in education: Interpretations and criticisms from science education. Handbook of research on applied learning theory and design in modern education içinde (s. 116-144). IGI Global.

Taber, K. S., ve Akpan, B. (Eds.). (2016). Science education: An international course companion. Springer.

Ültay, E. (2012). Implementing REACT strategy in a context-based physics class: Impulse and momentum example. Energy Education Science and Technology Part B: Social and Educational Studies, 4(1), 233-240. 
Ültay, E. (2014). İtme, momentum ve çarpışmalar konusuyla ilgili bağlam temelli ö̆renme yaklaşımina dayal açklama destekli REACT stratejisine göre geliştirilen etkinliklerin etkisinin araştırlmass. Yayımlanmamış doktora lisans tezi. Karadeniz Teknik Üniversitesi, Eğitim Bilimleri Enstitüsü, Trabzon.

Yaman, S. (2016). Ortaokul öğrencileri için fen öğrenmeye yönelik öz-yeterlik inanç ölçeği uyarlamass: Geçerlik ve güvenirlik çalş̧ması. Inönü Üniversitesi Ĕ̆itim Fakültesi Dergisi, 17(2).

Yllmaz, H., ve Çavaş, P. H. (2006). 4-E öğrenme döngüsü yönteminin öğrencilerin elektrik konusunu anlamalarma olan etkisi. Journal of Turkish Science Education, 3(1), 2-18.

Yiğit, M. (2015). 12. smuf öğrencilerinin hidrokarbon bileşikleri konusundaki kauramsal anlamalarmna, bağlam temelli öğrenme yaklaşımınin react stratejisine göre hazzrlanmış materyallerin etkisi. Yayımlanmamış yüksek lisans tezi. Giresun Üniversitesi, Fen Bilimleri Enstitüsü, Giresun.

\section{Kaynakça Bilgisi / Citation Information}

Deniş Çeliker, H. ve Kara, M. (2020). Fen öğretiminde REACT'ın etkileri: 21. yüzyıl becerileri ve fene yönelik öz yeterlilik inançları. OPUSUluslararası Toplum Araştırmaları Dergisi, 16(Eğitim ve Toplum Özel Say1s1), 5732-5763. DOI: 10.26466/opus.701189 